\title{
A mutation that affects fibril protein, development, cohesion and gene expression in Myxococcus xanthus
}

\author{
Daniel R. Smith† and Martin Dworkin \\ Author for correspondence: Martin Dworkin. Tel: +1612624 5634. Fax: +16126260623. \\ e-mail: martin@lenti.med.umn.edu
}

Department of

Microbiology, UMHC Box

196, University of

Minnesota, Minneapolis,

MN 55455-0312, USA

\begin{abstract}
Extracellular matrix fibrils are involved in the cell-cell interactions of the social prokaryote, Myxococcus xanthus. The fibrils are composed of a carbohydrate backbone and a set of five integral fibrillar proteins (IFPs) ranging from 14 to $66 \mathrm{kDa}$. As part of an attempt to understand the function(s) of the IFPs, a mutant (ifp-1:20) was generated that lacks IFP-1:20, one of the fibril proteins, as shown by Western blot analysis of both whole cells and isolated fibrils. Unlike those of the parent strain, the fibrils of the mutant were removed easily from the cells by shear forces. Development in ifp-1:20 was aberrant - aggregation and early mound formation were delayed by 6-10 $\mathrm{h}$ and mature fruiting bodies never formed. Myxospore production was also greatly reduced. Additionally, fibril-mediated cohesion in ifp-1:20 was changed. Cohesion resulted in chains of cells rather than the characteristic clumps of cells seen for the parent strain. Isolated ifp-1:20 fibrils, unlike wildtype fibrils, could not rescue cohesion of non-cohesive, fibril-negative dsp cells, supporting the notion that the fibrils were functionally altered. The mutation also reduced developmental gene expression by three- to fourfold in $\Omega 4521$, a transposon insertion mutant expressed early in development. Expression of a later developmental gene fusion was not affected, suggesting that the fibrils may not be required for later developmental gene expression. These data suggest that intact fibrils may function early in development to facilitate close cell proximity for signal exchange.
\end{abstract}

Keywords: Myxococcus xanthus, fibrils, end-to-end cohesion, pili

\section{INTRODUCTION}

The myxobacteria are Gram-negative bacteria that undergo social behaviour and a complex developmental life cycle (Dworkin, 1996). Myxobacteria are the paradigm of social behaviour among the bacteria (Dworkin \& Kaiser, 1993) and the synchronous behaviour of groups of myxobacterial cells is brought on by highly coordinated signals, regulated gene expression and cellcell contact (Shimkets, 1990). Social behaviour in myxobacteria, such as feeding (Shimkets, 1984), motility

Abbreviations: IFP, integral fibrillar protein; LV-SEM, low-voltage scanning electron microscopy.

† Present address: Department of Soil, Water and Climate, University of Minnesota, St Paul, MN 55108, USA.

The GenBank accession number for the sequence reported in this paper is U66899.
(Hodgkin \& Kaiser, 1977), cohesion (Shimkets, 1986), gene expression (Kuspa et al., 1992) and development, involves intimate cell-cell contact-mediated signalling (Hodgkin \& Kaiser, 1977). Contact plays a crucial role in myxobacterial interactions. For example, polar pili have been shown to mediate the close contact required for social motility (Kaiser, 1979; Wu et al., 1997). Not only do cells need to be brought together, but they need to remain in close contact through the action of cohesion (Shimkets, 1986).

The mediators of cohesion in myxobacteria are extracellular polysaccharide- and protein-containing structures known as fibrils (Arnold \& Shimkets, 1988a, b; Behmlander \& Dworkin, 1991). A strain termed $d s p$ (dispersed grower) fails to cohere or to develop and it lacks fibrils. Fibrils are also involved in gene expression (Chang \& Dworkin, 1994) and fruiting body formation (Arnold \& Shimkets, 1988b). These fibrils are morpho- 
logically similar to the surface appendages described for Salmonella typhimurium which are required for internalization into cultured epithelial cells (Ginocchio et al., 1994). In view of the role of cohesion and cell contact in myxobacterial behaviour, it is important to learn more about the structure and function of the mediating organelles.

Fibrils are 30-nm-wide structures composed of polysaccharide and tightly associated protein (integral fibrillar proteins or IFPs) at a ratio of approximately $1: 1$ (Behmlander \& Dworkin, 1994a). The component monosaccharides have been identified by HPLC analysis and include rhamnose, glucosamine, galactose, glucose and xylose (Behmlander \& Dworkin, 1994a). The network-like morphology seen in the fibrils is consistent with other extracellular polysaccharide structures when these are treated carefully during preparation (Mackie $e t$ al., 1979).

Nothing is known about the roles of the IFPs. A monoclonal antibody $(\mathrm{mAb} 2105)$, is specifically reactive with the IFPs of Myxococcus xanthus (Gill et al., 1985). Western-blot analysis with mAb 2105 showed five distinct reactive bands associated with isolated fibrils at 66, 40, 31, 20 and $14 \mathrm{kDa}$ (Behmlander \& Dworkin, 1991). Our data suggest that the complex banding pattern may be the result of more than one related gene resulting in a family of related proteins with crossreactive epitopes.

It was therefore the goal of this research to locate, sequence and disrupt the gene(s) responsible for the IFPs. This would help to answer at least two important questions: (1) what can be learned about the genetic organization of the process of IFP biosynthesis and (2) what role do the IFPs play in the functions of fibrils as mediators of cell-cell interactions in M. xanthus?

\section{METHODS}

Bacterial strains and growth conditions. $M$. xanthus strains (MD207, wild-type; DK4521, promoterless Tn5-lac at position $\Omega 4521$; DK4500, promoterless Tn5-lac at position $24500 ;$ MD1000,dsp) were grown in Casitone-Tris (CTT) broth (Hodgkin \& Kaiser, 1977) at $31^{\circ} \mathrm{C}$ with shaking at 300 r.p.m. For mutant selection, $3 \mathrm{mg}$ streptomycin $\mathrm{ml}^{-1}$ was incorporated into CTT agar plates (CTT broth with $1.5 \%$, $\mathrm{w} / \mathrm{v}$, agar added). Streptomycin-resistant mutants were routinely grown in CTT broth containing $1 \mathrm{mg}$ streptomycin $\mathrm{ml}^{-1}$. Escherichia coli (DH5 $\alpha$ ) was grown in Luria Broth (LB; Sambrook et al., 1989) with appropriate antibiotics for selection during cloning experiments, including $125 \mu \mathrm{g}$ ampicillin $\mathrm{ml}^{-1}$ and $25 \mu \mathrm{g}$ streptomycin $\mathrm{ml}^{-1}$. MX4 (ts) myxophage was used for transduction experiments (Campos et al., 1978).

M. xanthus chromosomal DNA isolation and molecular techniques. Chromosomal DNA was extracted with phenol/ chloroform/isoamyl alcohol (25:24:1, by vol.), precipitated with ethanol and purified using $\mathrm{CsCl}$ ultracentrifugation as described by Sambrook et al. (1989). Plasmid purification, agarose gel electrophoresis and Southern blot analysis were carried out as described by Sambrook et al. (1989).

DNA probe labelling. The oligonucleotide used in this study was generated by Integrated DNA Technologies Incorporated
(Iowa, USA) with the sequence: $5^{\prime} \mathrm{AA}(\mathrm{X}) \mathrm{TA}(\mathrm{X}) \mathrm{TT}(\mathrm{X})$ $\mathrm{GA}(\mathrm{X}) \mathrm{GT}(\mathrm{X}) \mathrm{AC}(\mathrm{X}) \mathrm{G} 3^{\prime}$ where $(X)$ is any one of the four $\mathrm{dNTPs}$. This sequence corresponded to part of the N-terminal amino acid sequence of isolated IFP-1:30 (Behmlander \& Dworkin, 1994b). The oligonucleotide was labelled using T4polynucleotide kinase and $\left[\gamma^{32} \mathrm{P}\right] \mathrm{dATP}$ (Sambrook et al., 1989). $\left[\alpha-{ }^{32} \mathrm{P}\right] \mathrm{dCTP}$ was randomly incorporated into potential DNA probes using a Random Primed DNA Labelling Kit (Boehringer Mannheim).

Electroporation. Electroporation in DH $5 \alpha$-was carried out as described by the manufacturer (Gene Pulser, Bio-Rad). The method of Kashefi \& Hartzell (1995) was used for M. xanthus electroporation.

Cloning of original $\mathbf{8 . 0} \mathbf{~ k b}$ fragment. Standard cloning procedures for E. coli were used (Sambrook et al., 1989). A preliminary Southern blot using PstI-digested MD207 genomic DNA probed with the oligonucleotide identified a single $8.0 \mathrm{~kb}$ band for cloning. Pst I-digested MD207 genomic DNA in the range of $8.0 \mathrm{~kb}$ was ligated with Pst I-digested, calf intestinal alkaline phosphatase (CIP)-treated plasmid p TZ18R (Pharmacia). Colony lifts, following the methods of Sambrook et al. (1989), probed with the oligonucleotide identified the target transformants. Clones with the insert were confirmed by Southern blot and restriction analysis.

Subcloning. Restriction analysis and Southern blotting revealed a $1.0 \mathrm{~kb}$ internal fragment containing $S p h \mathrm{I}$ and AatII ends that hybridized to the oligonucleotide probe under stringent conditions. Pst I linkers were added to this $1.0 \mathrm{~kb}$ fragment and it was subcloned into plasmid pTZ18R. The identity of the subclone was confirmed by restriction and Southern blot analysis using the oligonucleotide probe. This subclone was designated pP.1. Additionally, a larger subclone of $2.5 \mathrm{~kb}(\mathrm{pP} 2.5$ ) containing the $1.0 \mathrm{~kb}$ fragment was also generated to ensure adequate amounts of flanking MD207 DNA for later homologous recombination (Fig. 1).

DNA sequencing. Sequencing of pP.1 was done with the PRISM Ready Reaction DyeDeoxy Terminator Cycle Sequencing Automated Kit (Perkin Elmer) with empirical conditions as follows. The pP. 1 template was heated to $100{ }^{\circ} \mathrm{C}$ for $10 \mathrm{~min}$ and cooled rapidly on ice. Five microlitres of the denatured plasmid (3-5 $\mu \mathrm{g}$ DNA) was added to a tube containing $9.5 \mu \mathrm{l}$ reaction buffer, 20 pmol appropriate primer and 5 additional units of Taq DNA polymerase (Promega). PCR was then performed on the sample in a Perkin Elmer thermocycler model 480 . The cycle was as follows : rapid ramp to $96^{\circ} \mathrm{C}, 96^{\circ} \mathrm{C}$ for $30 \mathrm{~s}, 50^{\circ} \mathrm{C}$ for $15 \mathrm{~s}, 60^{\circ} \mathrm{C}$ for 4 min for a total of 25 cycles. The DNA sequence obtained for pP. 1 was analysed with the Wisconsin Genetics Computer Group's Sequence Analysis Software Package Version 7.0 (1990). Mapping, detection of possible restriction sites and putative amino acid coding regions, and sequence homology searches were performed.

Disruption of the coding region. Computer analysis showed a unique BstXI site located in the interior of a putative coding region. Site-directed mutagenesis was performed by insertion of a $2.0 \mathrm{~kb} \Omega$ fragment encoding streptomycin resistance (Prentki \& Krisch, 1984) into pP2.5 (Fig. 1). Identity of the disrupted pP2.5 with the $\Omega$ fragment insert was confirmed by restriction and Southern analysis. The resulting plasmid with the $\Omega$ fragment disrupting the coding region and creating an IFP-1:20 knock-out mutant was called pP2.5 2 .

Generation of the IFP mutant. Circular plasmid DNA ( $\mathrm{pP} 2.5 \Omega$, 1-5 $\mu \mathrm{g}$ ) was electroporated into MD207. Transductants were selected on CTT plus $3 \mathrm{mg}$ streptomycin $\mathrm{ml}^{-1}$. Transductants 

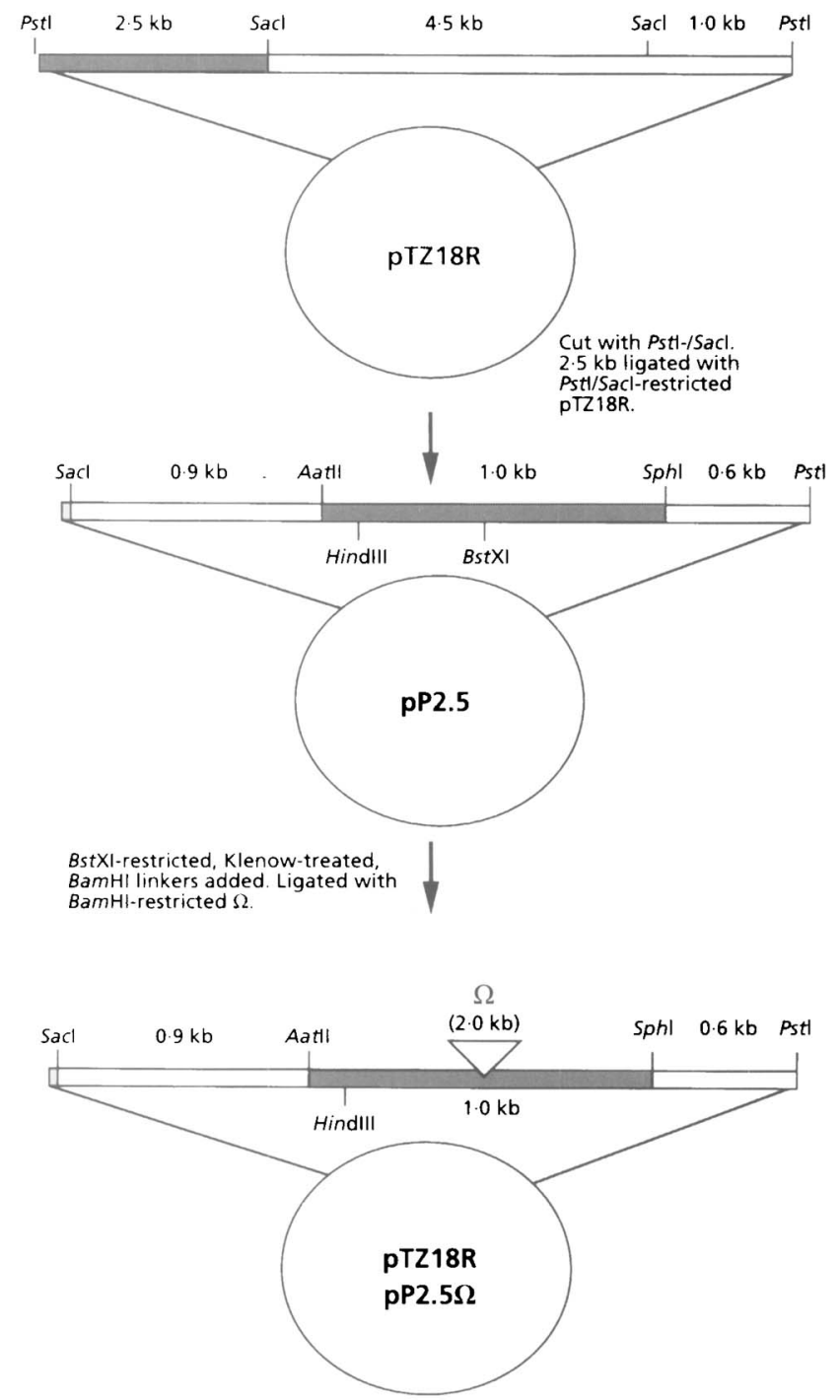

Fig. 1. Cloning and mutant generation scheme. The shaded bars indicate the cloned 993 bp gene.

appeared $6 \mathrm{~d}$ after plating and were re-streaked three times onto fresh streptomycin-containing plates. Colony lift and Southern analysis probing for the $\Omega$ fragment confirmed that the disruption occurred in the correct location.

PAGE/Western blotting. Discontinuous SDS-PAGE was performed as described by Laemmli (1970). Samples were prepared by sonication for $2 \mathrm{~min}$ on ice at $125 \mathrm{~W}$ with a microtip-equipped Sonifier Cell Disrupter W185 (Heat Systems-Ultrasonic Inc.). Protein was quantified using a Bio-Rad protein assay.

Electro- and Western blotting with mAb 2105 were carried out as described by Behmlander \& Dworkin (1991). Ponceau-S (Sigma) was used to stain total protein on the nitrocellulose according to manufacturer's instructions.

Low-voltage scanning electron microscopy (LV-SEM analysis). LV-SEM was used to visualize the mutant cell surface to detect any abnormalities associated with the mutant phenotype by the method of Behmlander \& Dworkin (1991), except that glass SEM chips were coated with a 1:100 dilution of
poly-L-lysine (Sigma) to allow adhesion of cells to the surface of the chip. The samples were examined using the Hitachi S900 low-voltage, high resolution scanning electron microscope.

Cohesion assay. The index of cohesion (i.o.c.), 100$\left[\left(A_{540} t_{x} / A_{540} t_{0}\right) \times 100\right]$, was quantified for $M$. xanthus strains as described by Behmlander \& Dworkin (1991).

Effect of shear forces on fibril-mediated clumps. Wild-type and ifp-1:20 cells were incubated under cohesion assay conditions for $90 \mathrm{~min}$. Cohered cells were removed by centrifugation at $300 \mathrm{~g}$ for $90 \mathrm{~s}$ and then passed through a 27.5 gauge hypodermic needle 10 times to disrupt clumps. The remaining cohered cells were again removed by low-speed centrifugation. The low-speed pellet was examined by quantitative dot blotting by the method of Behmlander \& Dworkin (1991) before and after disruption. End-point dilution was used as a parameter of reactivity with mAb 2105. Each spot was a twofold dilution of the previous spot. The inverse of the last dilution factor showing reactivity with $\mathrm{mAb} 2105$ was used as the relative immunoreactive unit.

Fibril isolation. Fibril isolation was performed by methods previously described (Behmlander \& Dworkin, 1991). The amount of carbohydrate in the fibrils was determined by the phenol/sulfuric acid assay using glucose as standard (Hodge \& Hofreiter, 1962).

Developmental assay. $M$. xanthus strains were grown to $3 \times 10^{8}$ cells $\mathrm{ml}^{-1}$, centrifuged and washed once in ice-cold TPM buffer (10 mM Tris/ $\mathrm{HCl}, \mathrm{pH} 7 \cdot 6,1 \mathrm{mM} \mathrm{K}{ }_{2} \mathrm{HPPO}_{4} /$ $\mathrm{KH}_{2} \mathrm{PO}_{4}, 8 \mathrm{mM} \quad \mathrm{MgSO}_{4}$ ). M. xanthus strains were resuspended to $1 \times 10^{10}$ cells $\mathrm{ml}^{-1}$ and $25 \mu \mathrm{l}$ spots were deposited on TPM agar plates (TPM buffer with $1.5 \%$ agar added). The spots were allowed to dry onto the agar surface under a sterile laminar-flow hood. The plates were incubated at $31^{\circ} \mathrm{C}$ for $72 \mathrm{~h}$ and development recorded photographically.

Transduction and gene expression. Strains DK4521 and DK4500 were chosen for transduction experiments since they express $\beta$-galactosidase in early and late development, respectively. Transduction of the ifp-1:20 mutation into DK4521 and DK4500 using MX4 (ts) phage (Campos et al., 1978) was completed as previously described. Cells were then diluted in CTT soft agar $\langle 0.4 \%$ agar $)$ and plated onto CTT $\left(1.5 \%\right.$ agar) containing $50 \mu \mathrm{g}$ kanamycin $\mathrm{ml}^{-1}$ and $2 \mathrm{mg}$ streptomycin $\mathrm{ml}^{-1}$ and grown at $31^{\circ} \mathrm{C}$. Transductants were detected after $6-9 \mathrm{~d}$. $\beta$-Galactosidase assays were performed as described by Kaplan et al. (1991).

\section{RESULTS}

\section{Molecular analysis}

Behmlander \& Dworkin (1994b) determined the Nterminal amino acid sequence of IFP-1:30. We constructed a degenerative oligonucleotide probe based on a portion of that sequence (underlined) : $\mathrm{NH}_{2}$-Val-ProPro-Pro-Pro-Thr-Asp-Pro-Ile-Val-Lys-Asg-Thr-ProVal-Val-Ser-Gly-Gly-Ala-Asn-Glu-Lys-Lys-Tyr-PheGlu-Val-Thr-Val-COOH. A $1 \mathrm{~kb}$ fragment that hybridized with the probe was isolated. The fragment was cloned in a plasmid designated pP.1 and sequenced.

Three interesting observations emerged from the sequence analysis. Firstly, the insert was found to be 


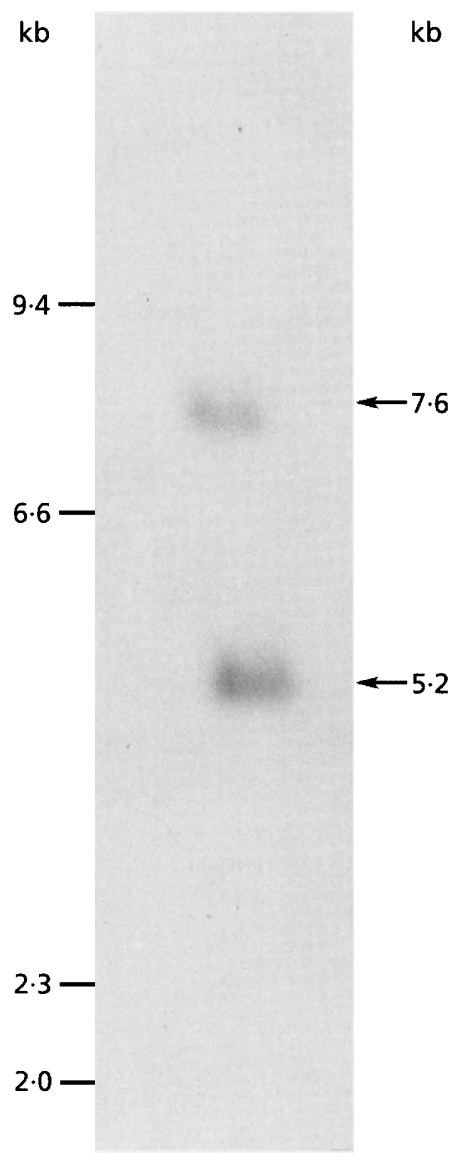

Fig. 2. Southern blot analysis of the MD207 genome restricted with Sacl, electrophoresed on a $0.8 \%$ agarose gel and probed with pP.1. Bands at 7.6 and $5.2 \mathrm{~kb}$ are apparent. The positions of size markers are shown on the left.

$993 \mathrm{bp}$ long and contained one complete putative ORF corresponding to $164 \mathrm{aa}$. The predicted protein product had a molecular mass of $19 \mathrm{kDa}$. From this deduced size of the cloned ORF, it became obvious that the oligonucleotide probe had hybridized with a DNA species other than IFP-1:30. Secondly, a sequence homologous to the $\mathrm{N}$ terminus of IFP-1:30 was found directly upstream of the probe-binding site. However, the sequence was not found at the $\mathrm{N}$ terminus of the putative ORF as with IFP-1:30, rather it is internal. Finally, there appears to be no homology with current sequences in the protein or DNA databases, suggesting that this sequence is novel and potentially interesting.

To explore the possibility that the oligonucleotide probe hybridized with a non-identical homologue of IFP-1:30, we performed several genomic Southern blots using different restriction digests to see if multiple reactive DNA fragments could be visualized. Fig. 2 shows that there were reactive fragments in SacI-restricted $M$. xanthus genomic DNA with apparent molecular masses of 7.6 and $5.2 \mathrm{~kb}$ when probed with the $993 \mathrm{bp}$ insert from pP.1. This suggests that the IFPs are encoded by at least two related genes that share some identity, according to Southern blot analysis.

\section{Characterization of the mutant: Western blot analysis}

The original probe was directed against IFP-1:30 but the resultant ORF that was cloned and mutated was calculated to have a molecular mass of $19 \mathrm{kDa}$. Behmlander \& Dworkin (1994b) had shown that one component of the IFP was a $20 \mathrm{kDa}$ protein. This suggested that the mutated IFP gene could be encoding the $20 \mathrm{kDa}$ IFP. Accordingly, if $p-1: 20$ was generated as described in Methods. Southern analysis of the mutant confirmed that the $\Omega$ fragment had inserted in the correct location and disrupted the single ORF (data not shown). The putative mutant did not hybridize with the vector sequence used as probe, indicating a double cross-over event (data not shown). To characterize the IFP phenotype of the mutant, we compared the Western immunoblots of the wild-type and mutant cells and isolated fibrils using mAb 2105. Fig. 3 shows Ponceau-S and Western blot analyses of fibrils from the wild-type and the mutant cells. The total amount of protein per unit of carbohydrate in the mutant was one quarter of that in the wild-type, as shown by Ponceau-S staining. In addition, the Western blots revealed that the total reactivity of mAb 2105 in the mutant cells was reduced. Finally, and most interestingly, the mutant was completely missing the band corresponding to IFP-1:20. This was in agreement with the predicted protein product of the cloned disrupted gene.

\section{Development in ifp-1:20}

We tested the ability of the mutant to undergo normal development. Fig. 4 shows the course of development of wild-type (a,b) and mutant cells (c, d). After $12 \mathrm{~h}$, the wild-type cells had formed typical aggregates while the mutant cells lagged behind. The wild-type had also formed mounds which would eventually become the fruiting bodies but the mutant formed few such mounds. After $48 \mathrm{~h}$, the wild-type had formed the typical mature, myxospore-filled fruiting bodies as evidenced by the dark colour of the fruiting bodies. The mutant had only progressed to the early fruiting-body-like structures that had not darkened. This indicated that sporulation was not complete. By $72 \mathrm{~h}$, sporulation in the mutant was only $14 \%$ of that of the wild-type (data not shown) and remained at this terminal level. We conclude from these experiments that the absence of IFP-1:20 seriously interferes with normal development.

\section{Studies of cohesion}

One possible explanation for the developmental defects in ifp-1:20 was that cohesion may be altered. Consequently, cohesion assays were performed on the mutant and wild-type cells. Cohesion was essentially $80-85 \%$ complete after $30 \mathrm{~min}$ and levelled off at about $95 \%$ 

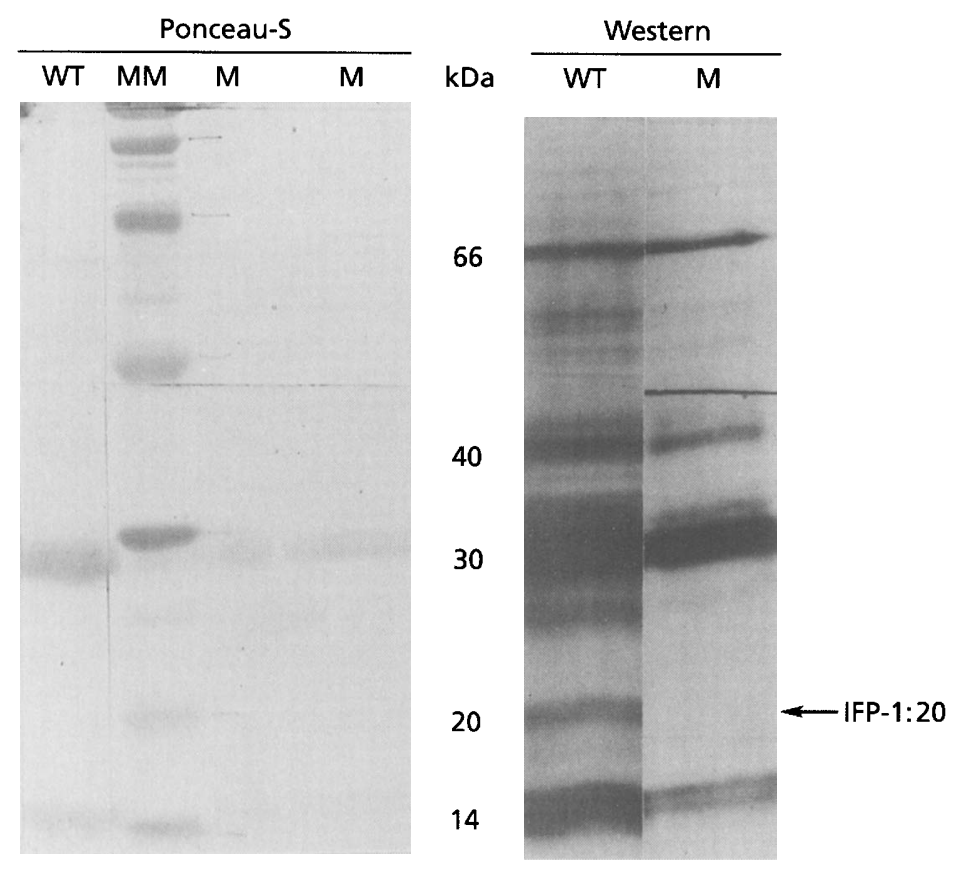

Fig. 3. Ponceau-S and Western blot analysis of fibrils with mAb 2105 containing $300 \mathrm{mg}$ carbohydrate from the mutant (M) and MD207 (WT). MM, molecular mass markers.

(data not shown). To our surprise, the mutant cells cohered slightly faster and to a greater extent than wildtype cells. However, microscopic examination of wildtype and mutant cells after 30 min of cohesion revealed that cohesion by the mutant was abnormal (Fig. 5), while clumps of several hundred cells predominated in the wild-type sample. The mutant showed a complete lack of clumps and instead contained numerous thin veils of cells. The veil apparently acted as a net during centrifugation and removed many of the cells from the supernatant, resulting in the artifactual apparent increase of cohesion in ifp-1:20. We conclude that the absence of IFP-1:20 interfered with normal cohesion. In addition, isolated mutant fibrils could not rescue cohesion in fibril-negative $d s p$ cells (data not shown) as could the addition of wild-type fibrils (Chang $\&$ Dworkin, 1994). This suggested that the fibrils of the mutant were functionally incomplete. Thus, the absence of IFP-1:20 not only prevents the proper association of the fibrils and the cells but also renders the fibrils unable to rescue cohesion in $d s p$.

\section{Characterization of the null mutant: LV-SEM analysis of mutant cells}

Would the absence of the $20 \mathrm{kDa}$ component of the IFP be manifested as some structural aberration of the fibrils? The physical change in cohesion suggested this possibility. We thus examined the ultrastructure of the fibrils from the mutant using LV-SEM (see Fig. 6). The previously reported rugose appearance of the cell surface and the fine fibrillar structure of the wild-type cells (Behmlander \& Dworkin, 1991) was readily visible (Fig. 6a). No fibril clusters, networks or retracted fibrillar material was visible in the mutant (Fig. 6b). This suggested that the absence of the $20 \mathrm{kDa}$ component of the IFP may have resulted in fibrils that were removed or destroyed during preparation for LV-SEM. It was likely that the shear forces generated by critical point drying may have removed the fibrils from the cells. This notion was further tested.

\section{Effect of shear forces on cohered mutant cells}

The effect of shear forces on fibril-mediated cohesion was tested in wild-type and mutant cells. The rationale was that if fibrils of the mutant were sensitive to and removed by shear forces, cohesion would be disrupted and essentially single cells would appear in the supernatant with a concomitant decrease in the immunoreactivity of cohered clumps of cells. Fig. 7 shows quantitative end-point dilution dot blots probed with mAb 2105 of both wild-type (a, c) and mutant (b, d). Cohered cells were tested for reactivity before $(a, b)$ and after (c, d) disruption. Relative immunoreactive units of cohered cells before disruption showed no difference (32 immunoreactive units for wild-type and mutant; Fig. $7 a, b)$. Once these cohered cells were disrupted, the relative immunoreactive units for the mutant was drastically reduced compared to wild-type cells (8 compared to 32, respectively; Fig. 7c, d). The immunoreactive units of the wild-type cells did not decrease, confirming that cohesion in wild-type cells is relatively resistant to shear forces. We conclude that the fibrils or fibrillar connections in the mutant cells were rendered more fragile by the removal of IFP-1:20.

\section{Transduction/gene expression studies}

There are a large number of Tn5-lac mutants of $M$. xanthus whose expression during development has been carefully timed (Kuspa et al., 1986). The dependence or 

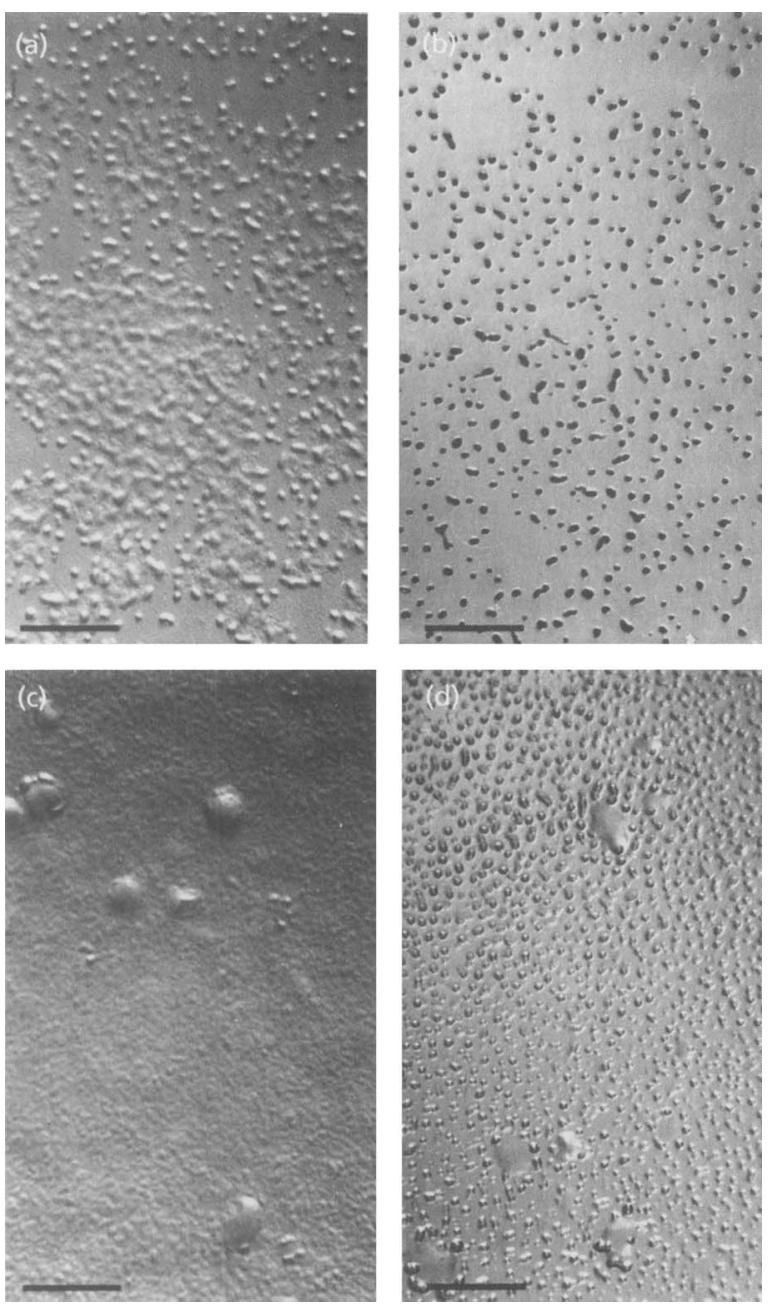

Fig. 4. Fruiting body formation in wild-type cells at $12 \mathrm{~h} \mathrm{(a)} \mathrm{and}$ $48 \mathrm{~h}$ (b) compared to mutant cells at $12 \mathrm{~h}$ (c) and $48 \mathrm{~h}$ (d). Bars, $500 \mu \mathrm{m}$.

non-dependence of expression of these promoterless reporter genes has been successfully exploited to determine the timing of expression of other mutated genes during development (Kuspa et al., 1986). We used two of these Tn $5-$ lac reporters $(\Omega 4521$ and $\Omega 4500)$ to determine the approximate time of expression of the IFP-1:20 gene and the dependence of gene expression on the IFP-1:20 mutation. Expression of $\Omega 4521$ begins normally at $2-5 \mathrm{~h}$ of development and reaches a maximum after $10-12 \mathrm{~h}$ (Fig. 8a). Expression of $\Omega 4500$ starts at $20-24 \mathrm{~h}$ and peaks at $35-37 \mathrm{~h}$ of development (Fig. $8 \mathrm{~b}$ ). $\Omega 4521$ was chosen because it is expressed during early development, during which period aggregation and other important early events occur (Kuspa et al., 1986). $\Omega 4500$ is expressed later in development when fruiting body formation and sporulation take place. The mutation in IFP-1:20 severely altered expression of $\Omega 4521$ - there was a steady slow increase in activity over time that never reached the levels seen in the parent strain.
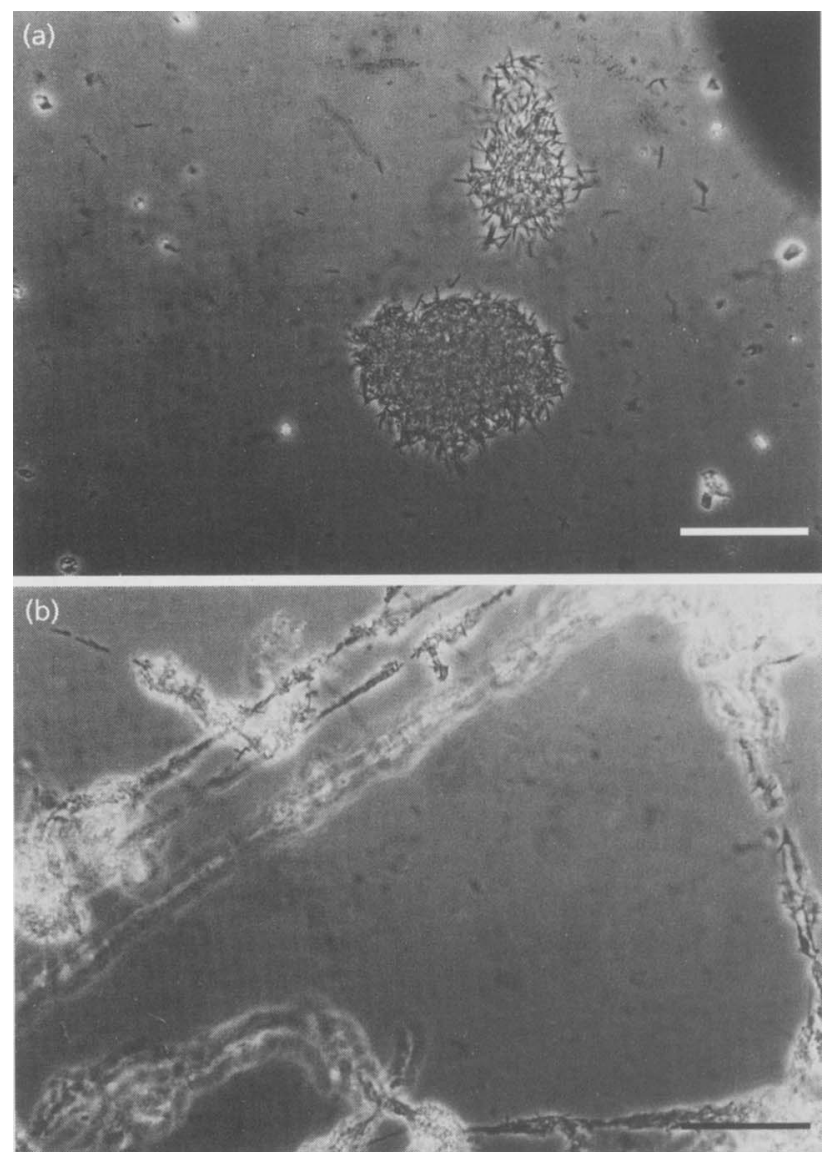

Fig. 5. Microscopic observations of wild-type (a) and mutant cells (b) after $30 \mathrm{~min}$ incubation under cohesion assay conditions. Bars, $50 \mu \mathrm{m}$.

Reduced IFP-1:20 expression, beginning at early development, is consistent with the observed developmental abnormalities in ifp-1:20.

The expression of the late gene $\Omega 4500$ in the presence of the IFP-1:20 mutation closely approximated expression of $\Omega 4500$ alone. $\beta$-Galactosidase was detected in both strains at $22 \mathrm{~h}$ of development and reached a maximum at $36 \mathrm{~h}$ (Fig. 8b). Thus, the IFP-1:20 mutation had no effect on expression of the late gene $\Omega 4500$.

\section{DISCUSSION}

\section{The gene for IFP-1:20 is part of a gene family}

One unresolved question regarding the IFPs concerns the nature of their complex banding pattern. A Western blot of isolated fibrils with mAb 2105 revealed five distinct bands (Behmlander \& Dworkin, 1991). Behmlander \& Dworkin (1994b) suggested two possible explanations: either the antibody recognizes common epitopes on different proteins or one protein exists in several forms. The authors concluded that the IFPs were all derived from a common subunit. To the contrary, we 

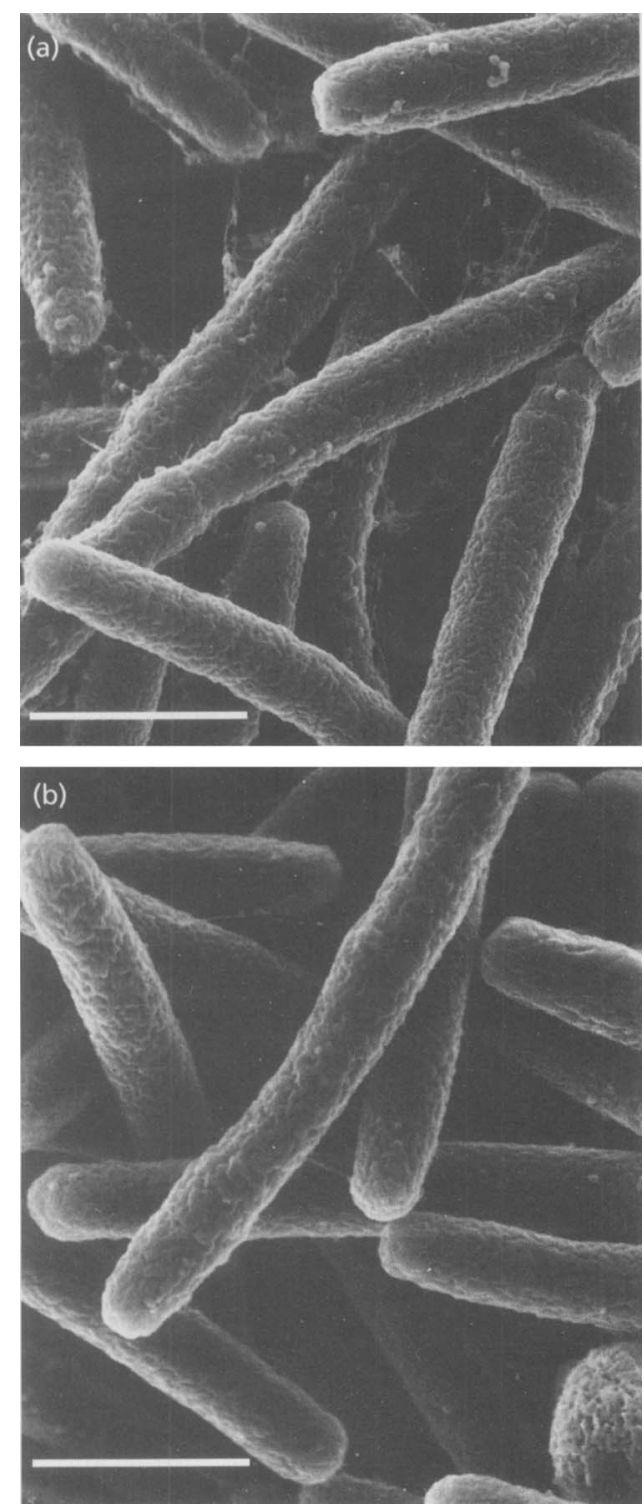

Fig. 6. LV-SEM analysis of wild-type vegetative cells (a) and mutant cells (b) showing lack of fibrillar material in the mutant. Bars, $1 \mu \mathrm{m}$.

now suggest that there are at least two genes encoding the IFPs. The evidence for this is as follows. Firstly, when the SacI-digested M. xanthus genome (there are no SacI sites in the cloned gene) was probed with the $993 \mathrm{bp}$ fragment from pP. 1 containing the putative ORF1, two distinct bands were located at $7 \cdot 6$ and $5 \cdot 2 \mathrm{~kb}$. Secondly, a degenerative oligonucleotide probe based on the known partial amino acid sequence of IFP- $1: 30$, reacted instead with a gene corresponding to a $20 \mathrm{kDa}$ protein. Finally, Western blot analysis of isolated ifp-1:20 fibrils clearly showed that the fibrils differentially lacked IFP$1: 20$, one of the components of the IFP complex. In addition, Western blot analysis of whole ifp-1:20 cells using mAb 2105 showed a complete lack of IFP-1:20, confirming that no protein is made. Thus, we conclude that the IFPs are encoded by at least two genes, one of which encodes IFP-1:20.

Gene families resulting from gene duplication have been reported previously, as in the case of serine/threoninelike kinases in myxobacteria. By using sequences derived from subdomains of eukaryotic serine/threonine kinases as PCR primers, a gene $(p k n 1)$ was isolated (Munoz-Dorado et al., 1991). It shares substantial similarity to the catalytic domains of eukaryotic kinases. By using a subdomain of $p k n 1$ as a probe, 23 additional bands on a Southern blot were visualized. There are now at least 26 putative kinase genes in M. xanthus.

Duplicated genes may have evolved to augment important events in the M. xanthus life cycle (Dworkin, 1996). There are two systems of motility, two parallel aggregation systems and, in the case of Stigmatella aurantiaca, three cohesion systems. In fact, many genes that are expressed during development can be mutated with no detectable change in behaviour, again suggesting several genes with overlapping functions.

\section{Loss of IFP-1:20 causes fragility in fibrils}

IFP-1: 20 could help in maintaining the structure of the fibril matrix. Emerson \& Ghiorse (1993) showed that isolated sheaths from Leptothrix discophora SP-6 are composed of carbohydrate and protein. Their studies showed that a protease-resistant protein is used to stabilize the sheath using interfibril disulfide bonds as a covalent 'glue'. If IFP-1:20 is used in a similar fashion, its absence would create less stable interfibril bonds and could cause the observed delicate nature of the ifp-1:20 fibrils.

\section{Deletion of IFP-1:20 affects development, cohesion and gene expression}

Development. Signal exchange plays a critical role during fruiting body formation (Kaiser \& Kroos, 1993). Five such signals, A-E, are required for development. When any of these signals is mutated, development is affected, ranging from delayed fruiting body formation to inhibited spore formation. The details of the actual exchange of the signals between cells and the involvement of fibrils in this exchange are not understood.

One of the signals, C-signal, is normally present in the extracellular matrix and may in fact be bound to the fibrils; it is involved in early and late changes during development (Shimkets \& Rafiee, 1990). The altered fibril fragility on ifp-1:20 cells may prevent the proper binding of the $\mathrm{C}$-signal to the polysaccharide matrix, thus preventing it from being presented effectively as a cell-cell signal. Additionally, the delicate nature of ifp1:20 fibrils could cause loss of the fibril matrix at times critical for C-signalling. This would cause a change in gene expression critical for development.

While C-signal is the only fibril-associated molecule whose function seems to be known (Shimkets \& Rafiee, 1990), there are at least three other molecules of 


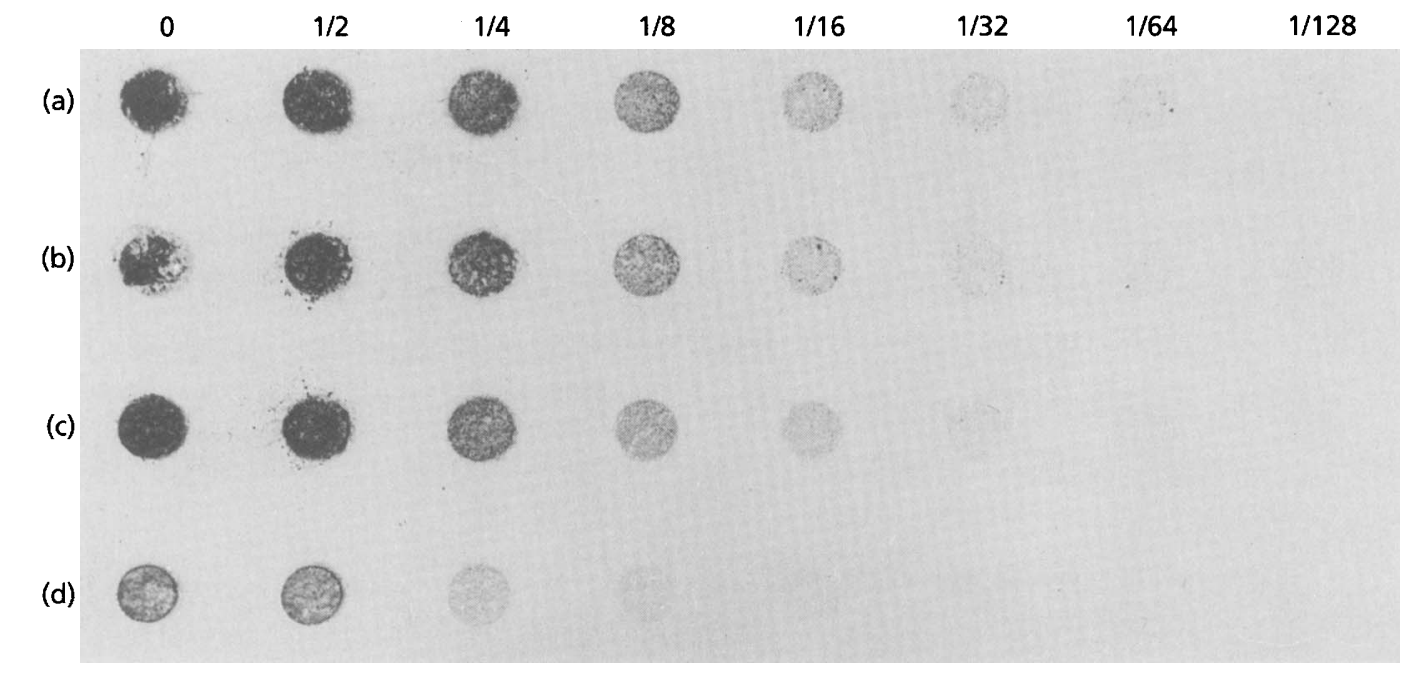

Fig. 7. Quantitative immuno-dot blot using mAb 2105 of wild-type cohered cells (a), mutant cohered cells (b), wild-type cohered cells after disruption (c) and mutant cohered cells after disruption (d). Twofold dilutions are shown along the top. Relative immunoreactive units were calculated as described in Methods.

unknown function that have been shown to be associated specifically with fibrils. These are dFA-1 (Clemens et al., 1991), a calcium-inducible $55 \mathrm{kDa}$ Stigmatella aurantiaca protein (Chang \& White, 1992), and the IFPs (Behmlander \& Dworkin, 1994b). This suggests that there may yet be additional important signalling molecules whose exchange requires fibrils, and any changes in the extracellular matrix involving fibril fragility or cohesion functions could affect the exchange of these signals.

Gene expression. Kuspa et al. (1986) showed that $\Omega 4521$ begins expression $1.5-2 \mathrm{~h}$ into development and that this is the earliest A-signal-dependent fusion. The concentration of A-signal around cells allows them to discern the density of the population around them (Kaplan \& Plamann, 1996). At cell densities below a critical threshold, cells will not express A-signal-dependent genes and will not develop. If the IFP-1:20 mutation impaired expression of A-signal-dependent genes, if $p$ $1: 20$ cells may not be able to respond correctly to the information about cell density and therefore will not undergo normal development. In addition, A-signal mutants were initially identified by their failure to form spores in fruiting bodies. The similar failure of if $p-1: 20$ cells to sporulate at wild-type levels correlates with the decreased expression of A-signal-dependent sporulation genes.

Why is development blocked in the ifp-1:20 cells while expression of $\Omega 4500$ remains unaffected? This would be consistent with earlier evidence (Kuspa et al., 1986) that there is not a single, linearly dependent pathway of developmental gene expression in $M$. xanthus but rather a series of branched pathways. For example, there are mutants that cannot sporulate but do aggregate and, conversely, mutants that cannot aggregate but do sporulate (Morrison \& Zusman, 1979). There are also many Tn5-lac insertions that show increased activity during development and so suggest that they are developmentally regulated; nevertheless, they show no change in developmental phenotype (Kuspa et al., 1986).

Additionally, the different dependence patterns of $M$. xanthus genes that are expressed at similar times may indicate that these genes possess complex regulatory regions that respond to several different signals. $\Omega 4500$ could exhibit complex regulation and so while ifp-1:20 could contribute to a change in expression, other factors may be necessary to abolish $\Omega 4500$ expression completely.

Cohesion. Experiments addressing contact in M. xanthus cells have shown that there is a distinction between sideby-side or end-to-end contact (Kim \& Kaiser, 1990). The 'veils' seen in ifp-1:20 could be lacking an important physical property such as side-by-side contact. It is conceivable, for example, that end-to-end contacts allow polar pili to mediate some form of cohesion. Unpublished observations of $\mathrm{pili}^{+} / \mathrm{fbril}^{-}$ mutants showed that some of these mutants did have some ability to cohere and that both pili and fibrils are necessary for wild-type cohesion. Pilus-mediated cohesion, coupled with altered fibrils, could have resulted in the decreased clumped aggregates seen in if $p-1: 20$. Further evidence for distinctions between types of physical contact comes from a study of C-factor in $M$. xanthus. Søgaard-Andersen et al. (1996) have found that there is a branched pathway for C-signalling in which there is interaction between $\mathrm{C}$ factor and the Frz motility proteins (McBride et al., 1993). Søgaard-Andersen \& Kaiser (1996) have recently presented a model which proposes that end-to-end contacts between the cells enhance the exchange of C-factor between the cells, inducing a cascade of Frz signalling events. This, in turn, reduces the reversal frequency of the gliding cells, 

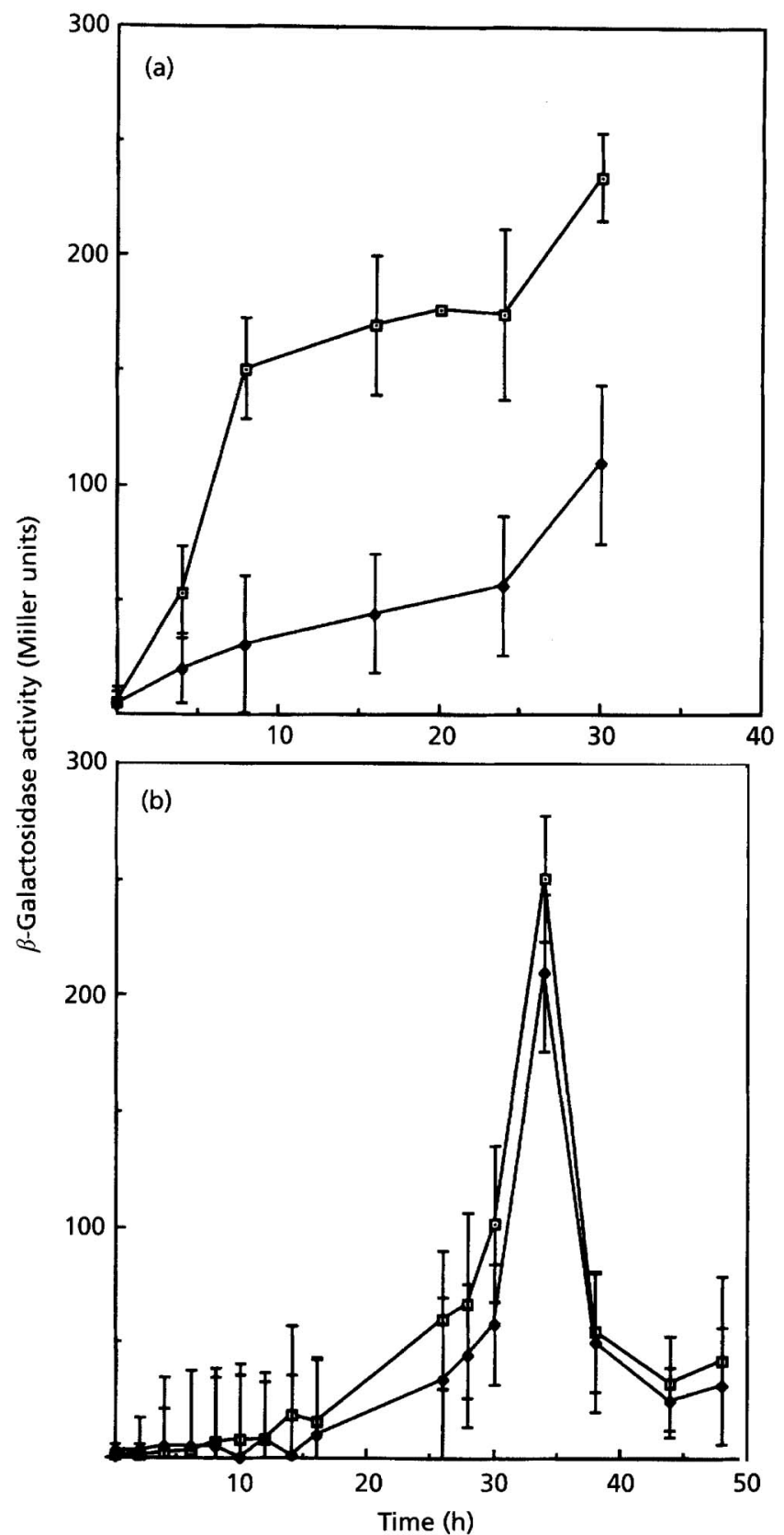

Fig. 8. Effects of the IFP-1:20 mutation on expression of $\Omega 4521$ (a) and $\Omega 4500$ (b). $\square$, Expression in the parent strain; $\bullet$, expression in the presence of ifp-1:20.

resulting in a higher local concentration of cells and the beginning of functional aggregation.

From the data presented here, we conclude that there could be two main cohesion systems regulating social behaviour. Side-by-side fibril-mediated cohesion could be necessary for initially bringing cells together in close proximity to allow for the earliest developmental signal exchange, i. e. A-signal. This could be followed by sideby-side-independent contact, which is not fibril-mediated but is necessary for later signal exchange, sub- sequent aggregation, gene expression and eventually fruiting body formation. The lack of IFP-1:20 and its consequent effect on fibril structure, may result in fewer or altered side-by-side or end-to-end contacts.

\section{ACKNOWLEDGEMENTS}

This work has been supported by Public Health Service grant GM 19957 from the National Institutes of Health.

\section{REFERENCES}

Arnold, J. W. \& Shimkets, L. J. (1988a). Cell surface properties correlated with cohesion in Myxococcus xanthus. J Bacteriol 170, 5771-5777.

Arnold, J. W. \& Shimkets, L. J. (1988b). Inhibition of cell-cell interactions in Myxococcus xanthus by Congo red. J Bacteriol 170, 5765-5770.

Behmlander, R. M. \& Dworkin, M. (1991). Extracellular fibrils and contact-mediated cell interactions in Myxococcus xanthus. J Bacteriol 173, 7810-7821.

Behmlander, R. M. \& Dworkin, M. (1994a). Biochemical and structural analysis of the extracellular matrix fibrils of Myxococcus xanthus. J Bacteriol 176, 6295-6303.

Behmlander, R. M. \& Dworkin, M. (1994b). Integral proteins of the extracellular matrix fibrils of Myxococcus xanthus. J Bacteriol 176, 6304-6311.

Campos, J. M., Geisselsoder, J. \& Zusman, D. R. (1978). Isolation of bacteriophage $\mathrm{MX4}$, a generalized transducing phage for Myxococcus xanthus. J Mol Biol 119, 167-178.

Chang, B. Y. \& Dworkin, M. (1994). Isolated fibrils rescue cohesion and development in the dsp mutant of Myxococcus xanthus. J Bacteriol 176, 7190-7196.

Chang, B. Y. \& White, D. (1992). Cell-surface modifications induced by calcium ion in the myxobacterium Stigmatella aurantiaca. J Bacteriol 174, 5780-5787.

Clemens, D. L., Chance, C. M. \& Dworkin, M. (1991). A development-specific protein in Myxococcus xanthus is associated with the extracellular fibrils. J Bacteriol 173, 6749-6759.

Dworkin, M. (1996). Recent advances in the social and developmental biology of the Myxobacteria. Microbiol Rev 60, 70-102.

Dworkin, M. \& Kaiser, D. (1993). Myxobacteria II. Washington, DC: American Society for Microbiology.

Emerson, D. \& Ghiorse, W. C. (1993). Role of disulfide bonds in maintaining the structural integrity of the sheath of Leptothrix discophora SP-6. J Bacteriol 175, 7819-7827.

Gill, J., Stellwag, E. \& Dworkin, M. (1985). Monoclonal antibodies against cell surface antigens of developing cells of Myxococcus xanthus. Ann Inst Pasteur Microbiol 136A, 11-18.

Ginocchio, C. C., Olmsted, S. B., Wells, C. L. \& Galán, J. E. (1994). Contact with epithelial cells induces the formation of surface appendages on Salmonella typhimurium. Cell 76, 717-724.

Hodge, J. E. \& Hofreiter, B. T. (1962). Determination of reducing sugar and carbohydrates. Methods Carbohydr Chem 1, 380-394 Hodgkin, J. \& Kaiser, D. (1977). Cell-cell stimulation of movement in nonmotile mutants of Myxococcus. Proc Natl Acad Sci USA 74, 2938-2942. 
Kaiser, D. (1979). Social gliding is correlated with the presence of pili in Myxococcus xanthus. Proc Natl Acad Sci USA 76, 5952-5956.

Kaiser, D. \& Kroos, L. (1993). Intercellular signalling. In Myxobacteria II, pp. 257-283. Edited by M. Dworkin \& D. Kaiser. Washington, DC: American Society for Microbiology.

Kaplan, H. B. \& Plamann, L. (1996). A Myxococcus xanthus cell density-sensing system required for multicellular development. FEMS Microbiol Lett 139, 89-95.

Kaplan, H. B., Kuspa, A. \& Kaiser, D. (1991). Suppressors that permit A-signal-independent developmental gene expression in Myxococcus xanthus. J Bacteriol 173, 1460-1470.

Kashefi, K. \& Hartzell, P. L. (1995). Genetic suppression and phenotypic masking of a Myxococcus xanthus FrzF (-) defect. Mol Microbiol 15, 483-494.

Kim, S. K. \& Kaiser, D. (1990). Cell alignment required in differentiation of Myxococcus xanthus. Science 249, 926-928.

Kuspa, A., Kroos, L. \& Kaiser, D. (1986). Intercellular signalling is required for developmental gene expression in Myxococcus xanthus. Dev Biol 117, 267-276.

Kuspa, A., Plamann, L. \& Kaiser, D. (1992). A-signalling and the cell density requirement for Myxococcus xanthus development. J Bacteriol 174, 7360-7369.

Laemmli, U. K. (1970). Cleavage of structural proteins during assembly of the head of bacteriophage T4. Nature 227, 680-685.

McBride, M. J., Hartzell, P. \& Zusman, D. R. (1993). Motility and tactic behavior in Myxococcus xanthus. In Myxobacteria II, pp. 285-305. Edited by M. Dworkin \& D. Kaiser. Washington, DC: American Society for Microbiology.

Mackie, E. B., Brown, K. N., Lam, J. \& Costerton, J. W. (1979). Morphological stabilization of capsules of group B streptococci, Types Ia, Ib, and III, with specific antibody. J Bacteriol 138, 609-617.
Morrison, C. \& Zusman, D. (1979). Mutants with temperaturesensitive stage-specific defects: evidence for independent pathways in development. J Bacteriol 140, 1036-1042.

Munoz-Dorado, J., Inouye, S. \& Inouye, M. (1991). A gene encoding a protein serine/ threonine kinase is required for normal development of M. xanthus, a Gram-negative bacterium. Cell 67, 995-1006.

Prentki, P. \& Krisch, M. (1984). In vitro insertional mutagenesis with a selectable DNA fragment. Gene 29, 303-313.

Sambrook, J., Fritsch, E. F. \& Maniatis, T. (1989). Molecular Cloning: a Laboratory Manual, 2nd edn. Cold Spring Harbor, NY : Cold Spring Harbor Laboratory.

Shimkets, L. J. (1984). Nutrition, metabolism, and the initiation of development. In Myxobacteria: Development and Cell Interactions, pp. 91-107. Edited by E. Rosenberg. New York: Springer.

Shimkets, L. J. (1986). Role of cell cohesion in Myxococcus xanthus fruiting-body formation. J Bacteriol 166, 842-848.

Shimkets, L. J. (1990). Social and developmental biology of the Myxobacteria. Microbiol Rev 54, 473-501.

Shimkets, L. J. \& Rafiee, H. (1990). CsgA, an extracellular protein essential for Myxococcus xanthus development. J Bacteriol 172, 5299-5306.

Søgaard-Andersen, L. \& Kaiser, D. (1996). C factor, a cell-surfaceassociated intercellular signalling protein, stimulates the cytoplasmic Frz signal transduction system in Myxococcus xanthus. Proc Natl Acad Sci USA 93, 2675-2679.

Wu, S. S., Wu, J. \& Kaiser, D. (1997). The Myxococcus xanthus pilT locus is required for social gliding motility although pili are still produced. Mol Microbiol 23, 109-121.

Received 18 April 1997; revised 15 July 1997; accepted 5 September 1997. 